\title{
OPEN Kinship of conditionally immortalized cells derived from fetal bone to human bone-derived mesenchymal stroma cells
}

\author{
S. Marozin ${ }^{1,3 凶}$, B. Simon-Nobbe ${ }^{1,3}$, S. Irausek ${ }^{1}$, L. W. K. Chung ${ }^{2}$ \& G. Lepperdinger ${ }^{1}$
}

The human fetal osteoblast cell line (hFOB 1.19) has been proposed as an accessible experimental model for study of osteoblast biology relating to drug development and biomaterial engineering. For their multilineage differentiation potential, hFOB has been compared to human mesenchymal progenitor cells and used to investigate bone-metabolism in vitro. Hereby, we studied whether and to what extent the conditionally immortalized cell line hFOB 1.19 can serve as a surrogate model for bone-marrow derived mesenchymal stromal cells (bmMSC). hFOB indeed exhibit specific characteristics reminiscent of bmMSC, as colony formation, migration capacity and the propensity to grow as multicellular aggregates. After prolonged culture, in contrast to the expected effect of immortalization, hFOB acquired a delayed growth rate. In close resemblance to bmMSC at increasing passages, also hFOB showed morphological abnormalities, enlargement and finally reduced proliferation rates together with enhanced expression of the cell cycle inhibitors p21 and p16. hFOB not only have the ability to undergo multilineage differentiation but portray several important aspects of human bone marrow mesenchymal stromal cells. Superior to primary MSC and osteoblasts, hFOB enabled the generation of continuous cell lines. These provide an advanced basis for investigating age-related dysfunctions of MSCs in an in vitro 3D-stem cell microenvironment.

Stromal cells have been extensively studied, also in regard to the corresponding stem cell type, which are most often called mesenchymal stem cells (MSC) as introduced by Arnold Caplan ${ }^{1}$. According to the "The International Society for Cell and Gene Therapy", the former represents a cell population with secretory, immunomodulatory and homing properties, while the latter is considered a tissue-borne stem cell population with the ability to selfrenew and generate progenitor cells prone to differentiate into various mesenchymal cell types ${ }^{2}$. Many studies have referred to the potential capability of this stem cell type in remodeling and regeneration of musculoskeletal tissues. For experimental analyses, primary MSC can be isolated from almost any mesenchymal tissue. However after explantation, and later on, during culture amplification, they undergo changes, which by and large resemble commonly known cellular aging phenotypes in conjunction with changes that are most likely due to donor-age and tissue of origin ${ }^{3}$. These undesirable and equally unpredictable deviations hampered up till now basic research in MSC biology.

Provided that, MSC biology may greatly benefit from the availability of a well-established in vitro MSC surrogate model. Several cell culture models have been proposed for studying bone formation in vitro. Immortalized and tumor cell lines have the advantage to provide an unlimited source of material and offer experimental reliability and reproducibility ${ }^{4}$. Some of the available cell models are also of human origin. Often they are derived from osteosarcomas, such as the cell line MG63 or SAOS- $2^{5}$. The cancerous origin of these cells constrains comparative studies for a better understanding of bone formation and osseous degeneration under physiological conditions. Despite many advantages, several studies concluded that such cell lines are inadequately representing the dynamic properties of normal cells in vivo, primarily due to their malignant nature and altered cellular physiology ${ }^{6}$.

${ }^{1}$ Department of Biosciences, University of Salzburg, Hellbrunnerstr. 34, 5020 Salzburg, Austria. ${ }^{2}$ Cedars-Sinai Medical Center, Dept. of Medicine, 8700 Beverly Blvd b106, Los Angeles, CA 90048, USA. ${ }^{3}$ These authors contributed equally: S. Marozin and B. Simon-Nobbe. ${ }^{\boxplus}$ email: sabrina.marozin@sbg.ac.at 
In order to circumvent the Hayflick limit, the catalytic component of human telomerase (hTERT) has been expressed in primary MSC. As a consequence thereof, life-span of MSC can be significantly increased, notably without limiting their inherent multi-lineage differentiation potential ${ }^{7,8}$. Besides retaining the parental cell properties, hTERT expressing MSC may escape in vitro senescence ${ }^{9}$. However, some minor indications of potential malignant transformations and chromosomal instability limited the use of various MSC lines that had been immortalized by means of constitutively expressing hTERT ${ }^{10-12}$.

As a matter of fact, MSC subjected to replicative or biological senescence show functional alterations, such as impaired differentiation potential and a decline of migratory ability ${ }^{3,13}$. Upon aging, bone-marrow MSC display a biased differentiation into adipocytes at the cost of osteoblasts. Divergent lineage fate decision with respect to adipogenesis over osteogenesis is believed to contribute to aging of mesenchymal tissue but the underlining molecular mechanisms are still unclear ${ }^{14,15}$.

In order to circumnavigate the aforementioned obstacles, we here investigated an osteoblastic non-tumorous cell line (hFOB1.19), which can be continuously expanded, thereby retaining both osteoblastic and adipogenic differentiation potentials. Our observations and analyses showed a high resemblance to MSC derived from adult donors, thus prompting that hFOB1.19 can be considered an appropriate cell model, which is amenable to solve still unanswered questions in MSC biology ${ }^{16,17}$.

\section{Results}

General properties of normal and transgenic human fetal osteoblast cells, hFOB1.19. Albeit predetermined to the osteogenic lineage, hFOB1.19 cells have been reported to also undergo adipogenic differentiation ${ }^{17}$. Exposure of hFOB cultures to $39^{\circ} \mathrm{C}$ resulted in spontaneous osteogenic differentiation as mineralized nodules were formed, which readily incorporated Alizarin Red and transcription of the osteogenicspecific markers became activated (Fig. 1A; Fig. S1). Adipogenesis was successfully achieved during 16 days at $39^{\circ} \mathrm{C}$ in the presence of adipogenic medium, as confirmed by the accumulation of intracellular lipid droplets, which were detected by Oil Red staining. This finding was also supported by transcriptional upregulation of the adipogenic factors PPAR $\gamma$. hFOB also share multiple surface markers with bone-marrow stem cells (Fig. 1B). Naive hFOB were positive for CD90, CD44, CD73 and CD105, while negative for CD106, CD19, CD34 and CD45. Additionally, hFOB cells were positive for CD146 (Fig. S2).

Primary mesenchymal stromal cells, which exhibit osteoblastic potential display a finite capacity to replicate in vitro, in particular when explanted from donors of advanced age. Often they can only be cultured for a limited time before they undergo senescence ${ }^{18,19}$. For this reason, generation of stable transgenic MSC lines is limited. Therefore, the feasibility of genetically engineering hFOB lines was approached by applying two different methods for gene transfer, lipofection and viral-based gene transfer. hFOB were plated at low density to achieve confluency of 70-90\%, and after $24 \mathrm{~h}$, transfection was carried out using Lipofectamine 2000. eGFP expression was determined $48 \mathrm{~h}$ after transfection by means of flow cytometry. Transfection efficiency was found low, especially at elevated cell concentration (data not shown). Therefore, a hFOB cell line expressing eGFP (hFOBeGFP) was generated with the aid of recombinant lentivirus particles delivering eGFP gene under the control of the human Uquitinase (hUbC) promoter (Fig. 2A). Stability of hFOB-eGFP was evaluated by means of flow cytometry revealing that GFP expression levels were stable over many passages (Fig. 2B). Another reporter line hFOB-hOC eGFP was generated, which enables the non-invasive monitoring of osteogenic commitment as in this line eGFP is expressed under the control of the human osteocalcin promoter (Fig. 2C). Exposure to the osteoinductive temperature of $39^{\circ} \mathrm{C}$ for 3 days significantly increased eGFP expression when compared to control cultures at $34^{\circ} \mathrm{C}$ (Fig. 2D).

Mesensphere culture of hFOB. 3D cell culture of MSC is preferred over 2D cell culture, since it allows cells to arrange in and self-organize an organotypic microenvironment, potentially mimicking in vivo cell-tocell interactions and ECM organization. Cell spheroids are a model for native tissues and have the potential to support relevant physiological questions in an in vitro context. For this reason, we generated hFOB mesenspheres using both ultra-low attachment plate and in static suspension on non-adhesive plates, and culturing them for a prolonged period.

$3 \mathrm{D}$ culture was successfully established in normal growth medium as well as in knock-out medium. Serumfree medium used for culture of spheroid-MSC, maintained proliferation and multipotency comparable to serumcontaining medium for adherent cultures ${ }^{20,21}$. In both cases, spheroids formed within $48 \mathrm{~h}$ (Fig. 3A,B) and their average diameter increased over time indicating active growth (Fig. 3C). The eGFP fluorescence signal faded in the center of the spheroids with time, indicating a possible reduction of vitality of the innermost parts of the cellular aggregates, which could be corroborated by histological analysis (Fig. S3).

To assess whether the generation of mesenspheres induced changes in adhesion and migration, hFOB spheroids were placed into plastic dishes, which provided a surface for cellular attachment in growth medium containing 10\% FBS. Spheroids readily adhered and cells spread-out displaying a typical hFOB phenotype, i.e. single-cell migration. Interestingly, cells which were closer to the inner core did not migrate and remained in situ (Fig. 3D).

Differentiation potentials of $\mathrm{hFOB}$ mesenspheres were also assessed. When incubated at $34^{\circ} \mathrm{C}$, they showed a larger size and exhibited a brighter Calcein signal, thus inferring higher viability and proliferation (Fig. 4A-C). As already described for $2 \mathrm{D}$ cultures at $39^{\circ} \mathrm{C}$, also $3 \mathrm{D}$-cultivated cells ceased proliferation and commenced osteogenic differentiation as indicated by positive calcium staining and up-regulation of osteogenic marker gene expression (Fig. 4A-C; Fig. S4). Likewise, by incubation of spheroids at $39^{\circ} \mathrm{C}$ in adipogenic medium, high lipid droplet content was apparent as indicated by a stronger staining with Autodot in comparison to the controls maintained at $34^{\circ} \mathrm{C}$. These findings were also supported by a robust up-regulation of PPAR $\gamma$ (Fig. $\left.4 \mathrm{~B}-\mathrm{D}\right)$. 
A Differentiation $\left(39^{\circ} \mathrm{C}\right)$
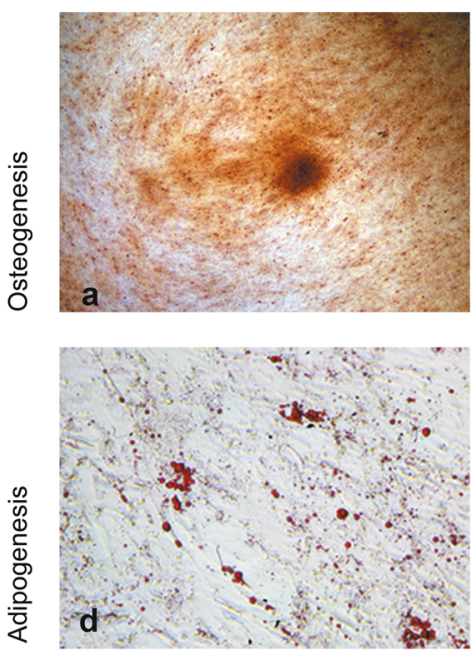

Control $\left(34^{\circ} \mathrm{C}\right)$
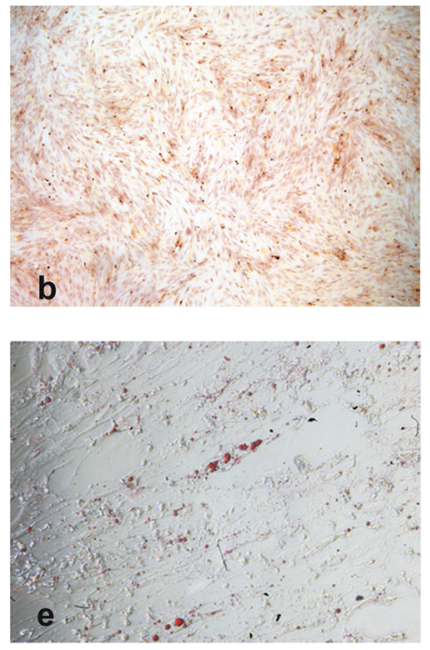

C

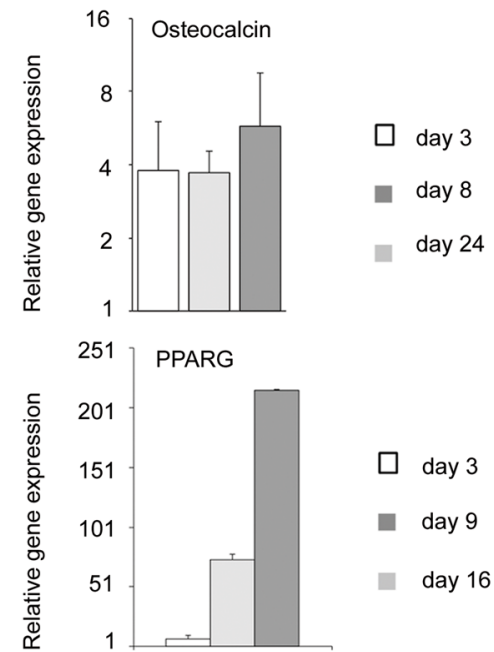

B
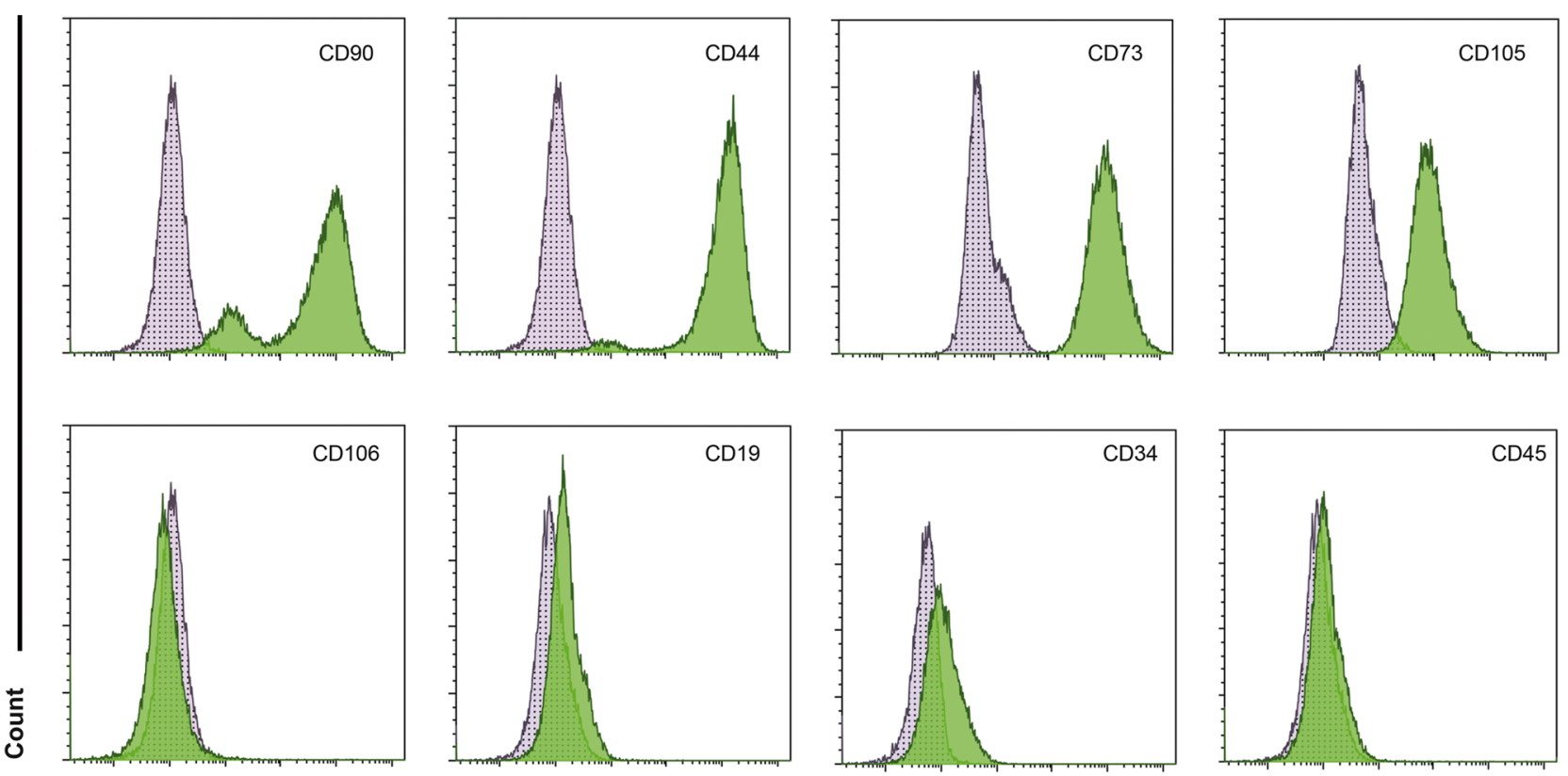

Fluorescence

Figure 1. Characterization of hFOB1.19 cells. (A) Differentiation capacity towards the osteogenic lineage was tested after cell seeding at a density of $1 \times 10^{5}$ cells $/ \mathrm{cm}^{2}$ in DMEM:F12 medium at $34{ }^{\circ} \mathrm{C}$ and $5 \% \mathrm{CO}_{2} / 20 \% \mathrm{O}_{2}$. (a) The following day osteogenic differentiation was induced by shifting the temperature to $39^{\circ} \mathrm{C}$. After 24 days, cells were stained with Alizarin Red S. (b) As a control, cells were cultivated at $34^{\circ} \mathrm{C}$ for 24 days and also stained with Alizarin Red. (c) Corresponding qPCR of the osteogenic marker (Osteocalcin) was normalized to YWHAZ (Tyrosine 3-monooxygenase) gene. (d) In order to examine adipogenic differentiation capacity, cells were seeded at a density of $1.5 \times 10^{5}$ cells $/ \mathrm{cm}^{2}$ in DMEM:F12 medium at $34{ }^{\circ} \mathrm{C}$ and $5 \% \mathrm{CO}_{2} / 20 \% \mathrm{O}_{2}$. Adipogenic differentiation was induced by shifting the temperature to $39^{\circ} \mathrm{C}$ and supplementing the medium with the differentiation mix ( $0.5 \mathrm{mM}$ isobutyl-methylxanthine, $1 \mu \mathrm{M}$ dexamethasone, $10 \mu \mathrm{M}$ insulin, $60 \mu \mathrm{M}$ indomethacin) for 16 days. (e) Adipogenic control cells were incubated in DMEM:F12 medium at $34{ }^{\circ} \mathrm{C}$ and $5 \% \mathrm{CO}_{2} / 20 \% \mathrm{O}_{2}$ for 16 days. (f) Expression levels of the adipogenic marker (PPARg) was assessed by qPCR. For normalization YWHAZ (Tyrosine 3-monooxygenase) was used as a reference gene. (B) Cultures of hFOBs at 34 ${ }^{\circ} \mathrm{C}, 20 \% \mathrm{O}_{2}$ were subjected to surface antigen analysis by flow cytometry. Flow cytometry was performed using Cytoflex $\mathrm{S}$ and the analysis performed with Kaluza software (Beckman-Coulter). Surface antigen in green and isotype control in grey. 
A

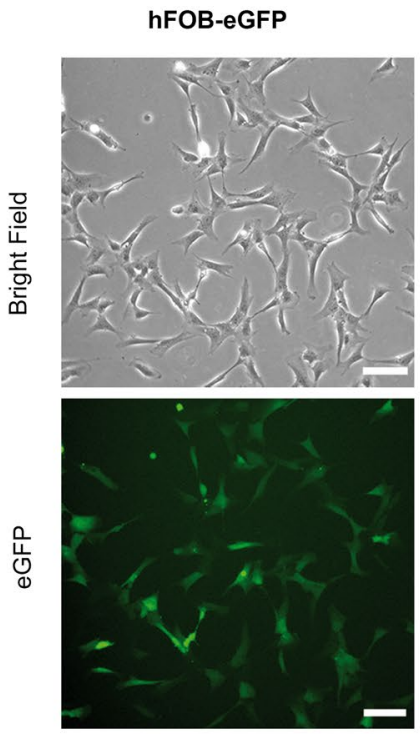

C

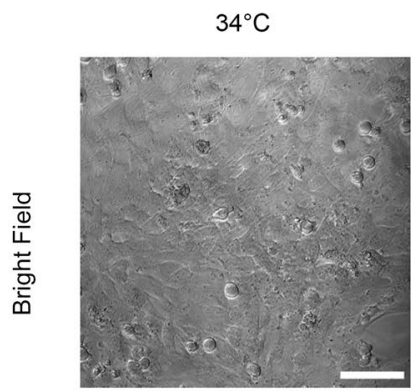

hFOB-hOC EGFP
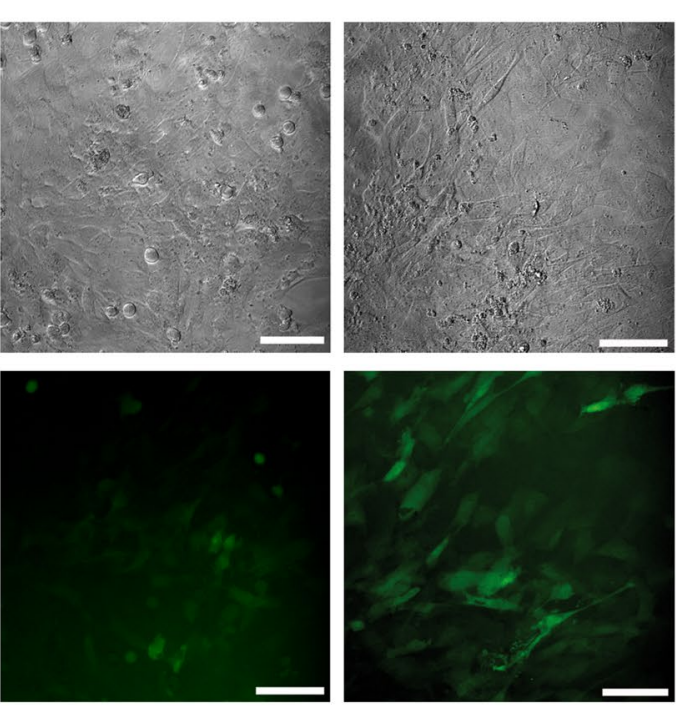

B

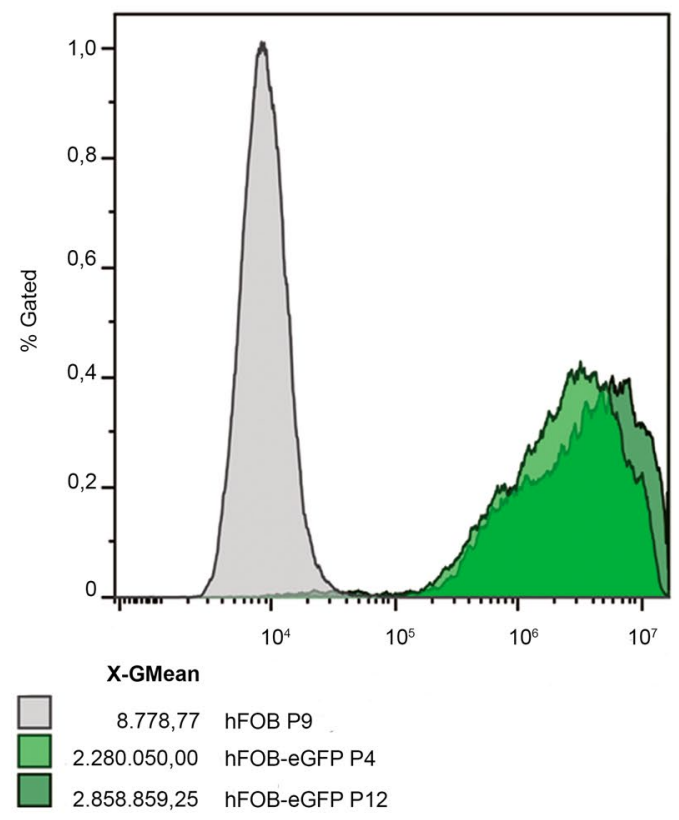

D

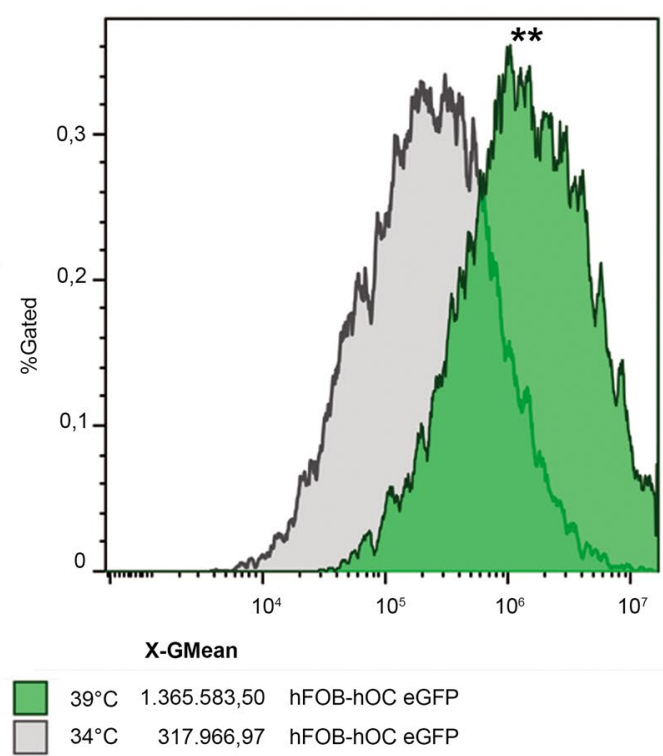

Figure 2. Transgenic hFOB reporter cell lines. (A) hFOB cells were transduced with a recombinant lentivirus vector bearing the reporter construct UbC-eGFP resulting in the cell line hFOB-eGFP. Constitutively active expression of eGFP was visualized by fluorescence microscopy. Bars indicate $100 \mu \mathrm{m}$. (B) Stable eGFP expression over cell passaging was assessed by flow-cytometry comparing wild-type hFOB (in grey) with hFOBeGFP (in green) at low (P4) and high cell passage (P12). Data acquisition and analysis were performed by means of Cytoflex S, software CytExpert and Kaluza. (C) An inducible cell line expressing eGFP under the control of the full length promoter for the human osteocalcin (hFOB-hOC eGFP) was transduced and differentiation was induced by incubation at $39^{\circ} \mathrm{C}$ for 3 days. Images of cells incubated at $34^{\circ} \mathrm{C}$ (undifferentiated control) versus induced cultures at $39^{\circ} \mathrm{C}$ were taken to monitor eGFP expression. (D) Representative histograms of flow-cytometric analysis of reporter gene expression in hFOB-hOC eGFP activated at $39^{\circ} \mathrm{C}$ (green) for 3 days. Uninduced cells cultured at $34^{\circ} \mathrm{C}$ (in grey) displayed a basal expression of eGFP. Geometric mean of fluorescence intensity is indicated. Statistical significance of reporter activity at $39^{\circ} \mathrm{C}$ of three independent experiments was calculated using an unpaired Student $t$ test. 
A
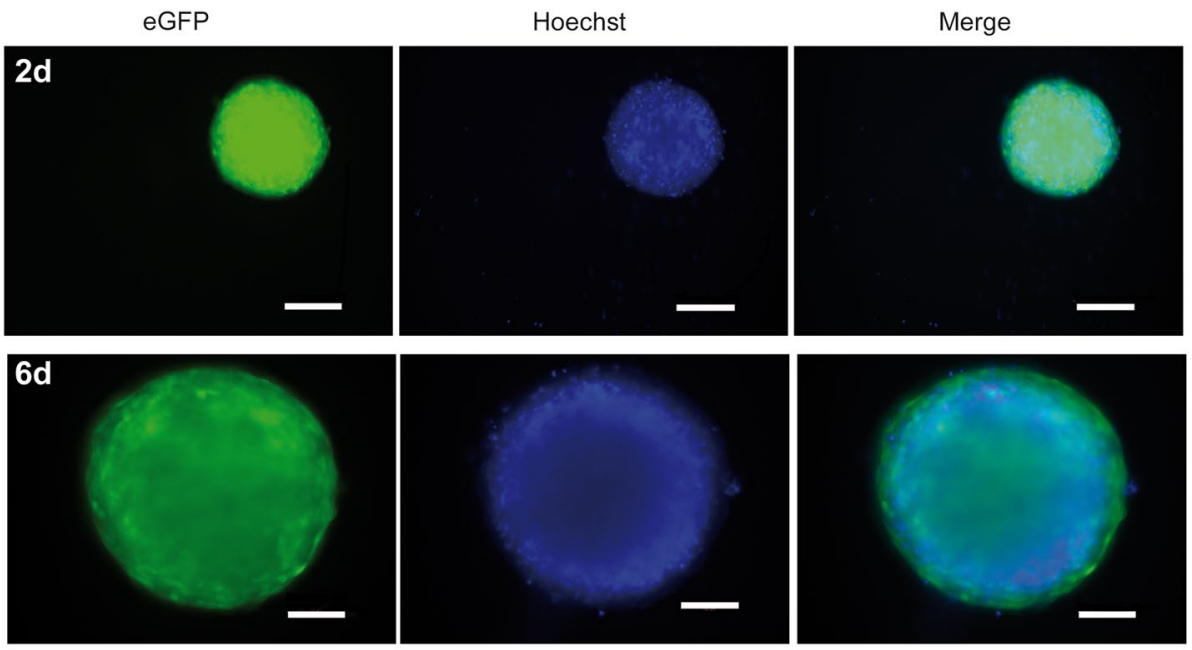

B
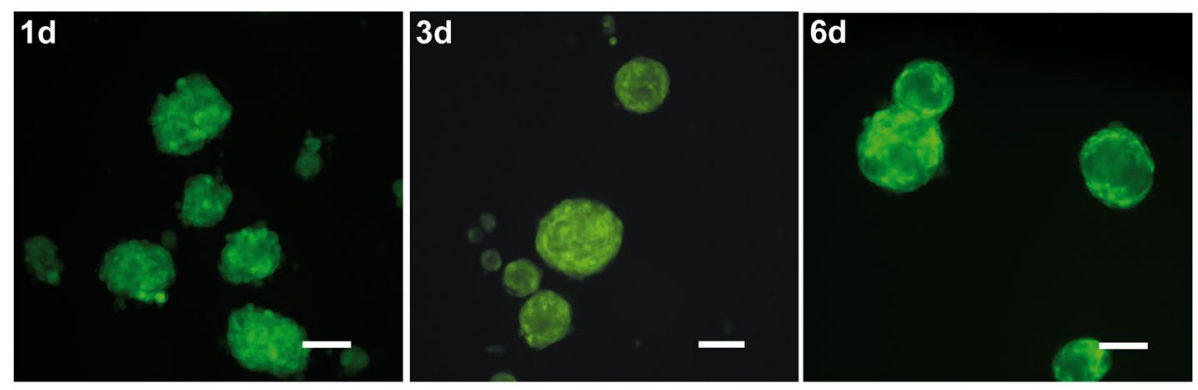

C

D
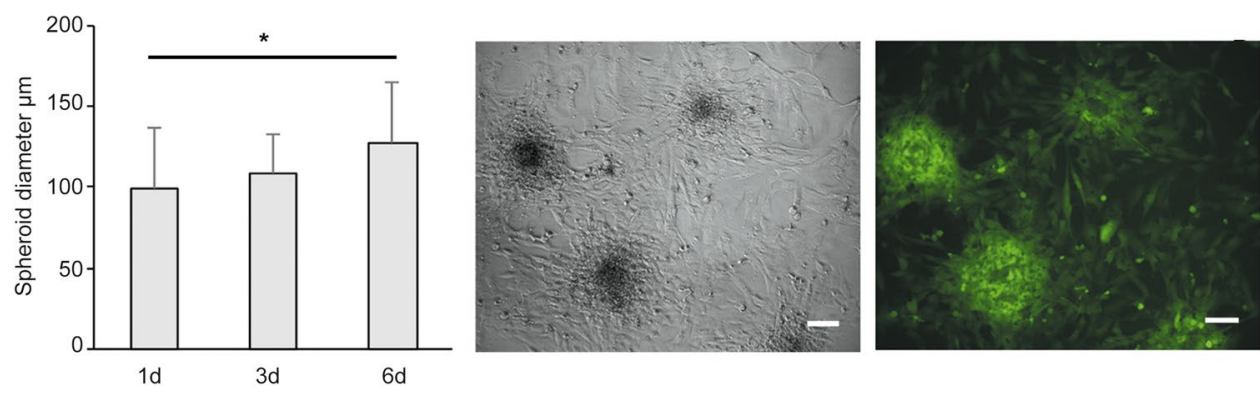

Figure 3. Scaffold-free spheroids. (A) hFOB expressing eGFP (hFOB-eGFP) were allowed to settle in low attachment 96-well U-bottom plates. After aggregation, spheroids were grown for 6 days. Living-cell staining with Hoechst was performed together with image acquisition at day 2 and 6 post-seeding. (B) hFOB-eGFP cells, at the density of $10^{6}$ cells/well, were allowed to form spheroids in static suspension in a low attachment Petri dish in the absence of serum. Serum was replaced by 15\% Knockout Serum Replacement (KSR) during the entire experiment. Representative images of spheroids growing for 6 days at $34^{\circ} \mathrm{C} 20 \% \mathrm{O}_{2}(\mathrm{DMiL}$ Leica). Scale bars indicate $100 \mu \mathrm{m}$. (C) The diameters of the spheroids were assessed using LAS X software (Leica). ${ }^{*} \mathrm{P}=0.04$. (D) Cell outgrowth from hFOB-eGFP spheroids obtained in KSR medium was examined one day after spheroid formation. Aggregates were transferred to complete growth medium at $34{ }^{\circ} \mathrm{C} 20 \% \mathrm{O}_{2}$ in a 24 -well cell culture grade plastic plate. Outgrowth of cells from spheroids was observed 3 days after transfer (DmiL, Leica, LAS X software).

Cell growth at variant culture conditions. In addition to the influence of temperature, also effects due to partial oxygen tension were monitored. Overall, the semi-permissive temperature of $37^{\circ} \mathrm{C}$ supported a faster growth but negatively affected colony formation in comparison to the recommended culture temperature of 34 ${ }^{\circ} \mathrm{C}$. The latter indicated an effect on potential stemness characteristics of hFOB. Therefore, hFOB monolayer grown under $20 \% \mathrm{O}_{2}\left(34{ }^{\circ} \mathrm{C}\right)$, were re-seeded at a density of 10 cells $/ \mathrm{cm}^{2}$, and were now allowed to form colonies either under $20 \% \mathrm{O}_{2}$ (normoxic) or $3 \% \mathrm{O}_{2}$ (hypoxic) conditions at $34^{\circ} \mathrm{C}$ and $37^{\circ} \mathrm{C}$. A higher number of colonies were formed at $34^{\circ} \mathrm{C}$ in comparison to $37^{\circ} \mathrm{C}$. At $3 \% \mathrm{O}_{2}$ colony formation was favored at both temperature conditions (Fig. 5A). Colonies grown at $37^{\circ} \mathrm{C}$ exhibited bigger sizes and higher densities, which indicated that the physiological temperature of $37^{\circ} \mathrm{C}$ reinforced hFOB proliferation. Real-time monitoring of proliferation at 34 ${ }^{\circ} \mathrm{C}$ and $37^{\circ} \mathrm{C}$ under normoxic or hypoxic conditions was performed using electrical impedance as the readout of 
A

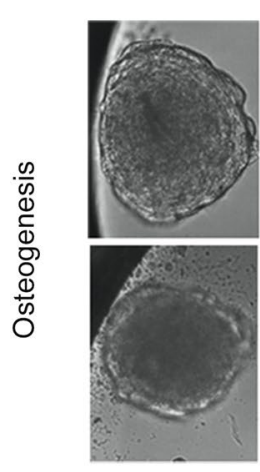

C
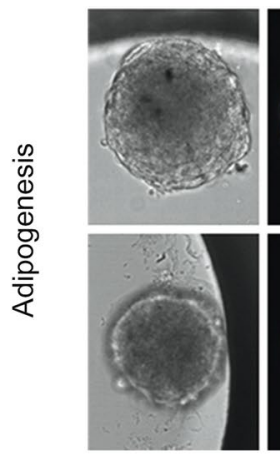

Calcein

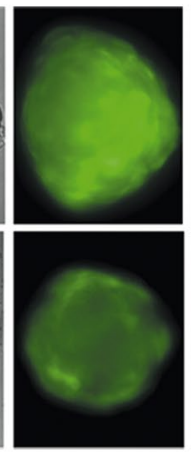

Calcein
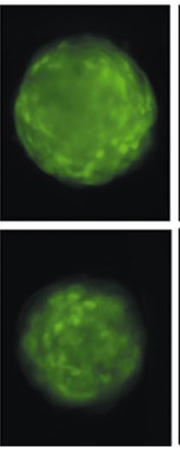

$\mathrm{XO}$

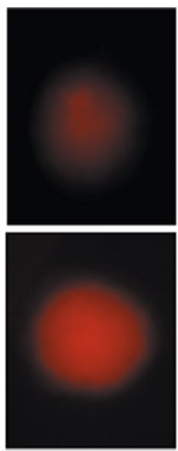

Autodot
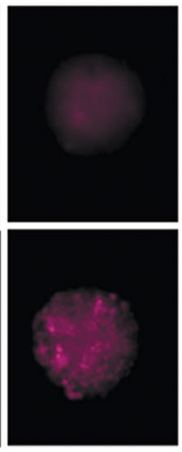

Merge

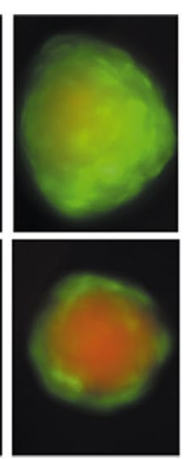

Merge

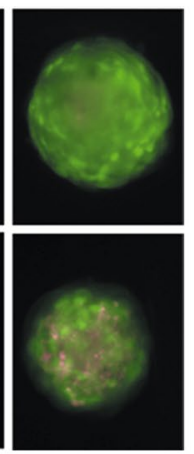

B

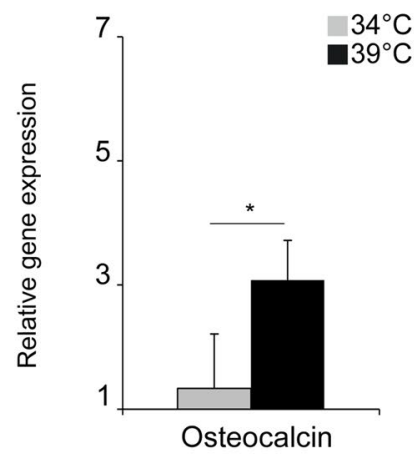

D

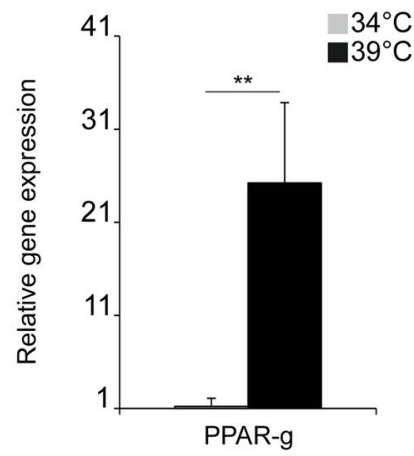

Figure 4. Differentiation of hFOB spheroids. (A) Spheroids were obtained using low attachment plates. 1000 cells were seeded per well and allowed to aggregate at the bottom of the plates for $48 \mathrm{~h}$ at $34^{\circ} \mathrm{C}$. Thereafter, plates were incubated for 3 days at $34^{\circ} \mathrm{C}$ (upper panel) or at $39^{\circ} \mathrm{C}$ (lower panel). Spheroids were stained with Calcein-AM (Calcein) and calcium deposition was visualized with Xylenol Orange (XO). For adipogenic differentiation (C) spheroids were incubated in adipogenic medium at $34^{\circ} \mathrm{C}$ (upper panel) or $39^{\circ} \mathrm{C}$ (lower panel) for 3 days. Cells were live-stained with Calcein and Autodot (pink). Images were taken using a DMi8 microscope (Leica) and acquisition analysis was performed with LAS X Software. (B, D) Quantitative PCR for the genes osteocalcin and PPAR $\gamma$ was performed to confirm osteogenic or adipogenic differentiation at day 4 post induction. Relative expression was normalized to hFOB cells grown in $2 \mathrm{D}$ at $34^{\circ} \mathrm{C}$.

an xCELLigence system. Cell growth, as an extrapolation of the Cell Index, was faster when cells were cultured at $37^{\circ} \mathrm{C}$ in comparison to the permissive temperature of $34^{\circ} \mathrm{C}$. At $37^{\circ} \mathrm{C}$, proliferation rate was not affected by oxygen tension at later times (see 5-7 days post seeding) compared to $34^{\circ} \mathrm{C}$ (Fig. 5B). Indeed at $34{ }^{\circ} \mathrm{C}, 3 \% \mathrm{O}_{2}$ had a positive influence on growth at day 6 of culture in comparison to $20 \% \mathrm{O}_{2}$ (Fig. 5C).

The semi-permissive temperature of $37^{\circ} \mathrm{C}$ supported a faster growth but negatively affected colony formation when grown in low density cultures in comparison to the recommended culture temperature of $34^{\circ} \mathrm{C}$. It is however also conceivable that the temperature of $37^{\circ} \mathrm{C}$ altered the conformation of the mutant tsA58 SV 40 Large $\mathrm{T}$ antigen in a great number of cells allowing them to follow their specified differentiation along the osteogenic lineage. Nevertheless, some cells were still supported by SV40 activity and formed colonies of larger size and density due to a higher growth rate at this temperature. At $37^{\circ} \mathrm{C}, 20 \%$ oxygen tension resulted in the lowest number of colonies while a hypoxic condition restored stemness independent of SV40 Large T antigen activity.

Also the migration potentials of cells grown either under standard oxygen tension or hypoxic condition at $34^{\circ} \mathrm{C}$ versus $37^{\circ} \mathrm{C}$ were investigated. Compared to $3 \%$ oxygen tension, $20 \%$ partial oxygen pressure resulted in faster gap closure irrespective of culture temperature. (Fig. 5D,E). After $6 \mathrm{~h}$ at $3 \%$ oxygen gap closure was more prominent at $34^{\circ} \mathrm{C}$ than at $37^{\circ} \mathrm{C}$.

Long-term culture restricts proliferation of hFOB. Age-related changes in bmMSC include loss of stemness and proliferative capacity. These features have been also observed during long-term culture, showing a clear decline in replicative lifespan ${ }^{13,22}$. We therefore investigated cellular fitness in long-term culture. We noticed that at higher passages, cells underwent morphological changes and their growth rates declined. Cells at high passages (P20) showed an enlarged and more pronounced flat phenotype in comparison to those at low passage (P7) (Fig. 6A). Colony formation as an indicator for stemness was assessed at $34{ }^{\circ} \mathrm{C}$ and $37^{\circ} \mathrm{C}$ in the presence of $20 \%$ oxygen. Colony forming unit (CFU) frequency was gradually reduced during subculture from low (5-7), to intermediate (10-12), to high passage (18-20), especially at $37^{\circ} \mathrm{C}$ (Fig. $\left.6 \mathrm{~B}\right)$. Intermediate-passage cells from colonies generated at $37^{\circ} \mathrm{C}$ and $3 \% \mathrm{O}_{2}$ were used for a second round of colony-formation assay. Under 
A

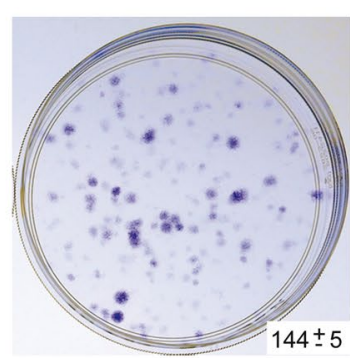

34-3

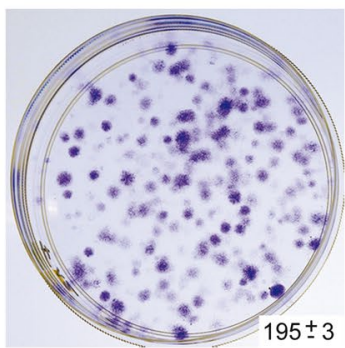

$37-20$

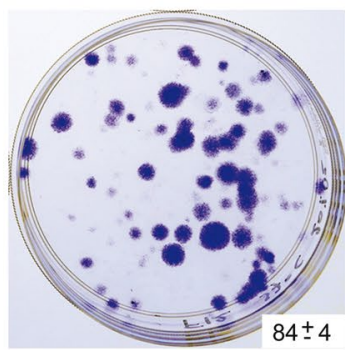

$37-3$

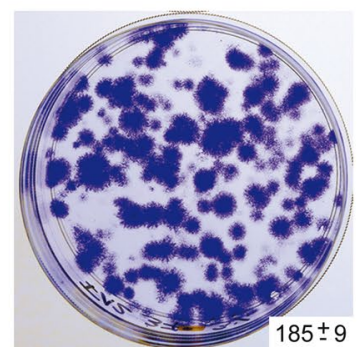

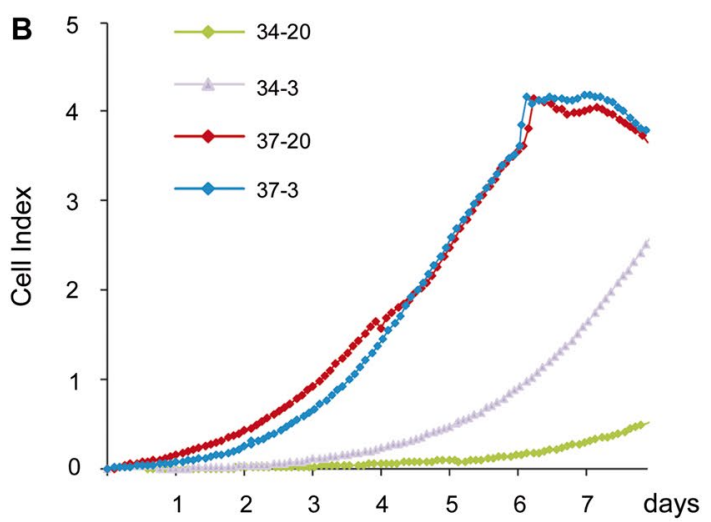

D

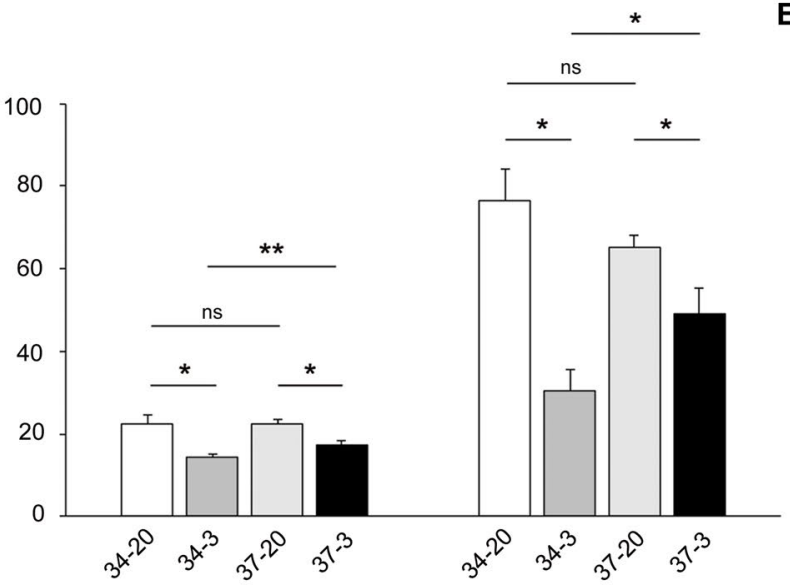

C
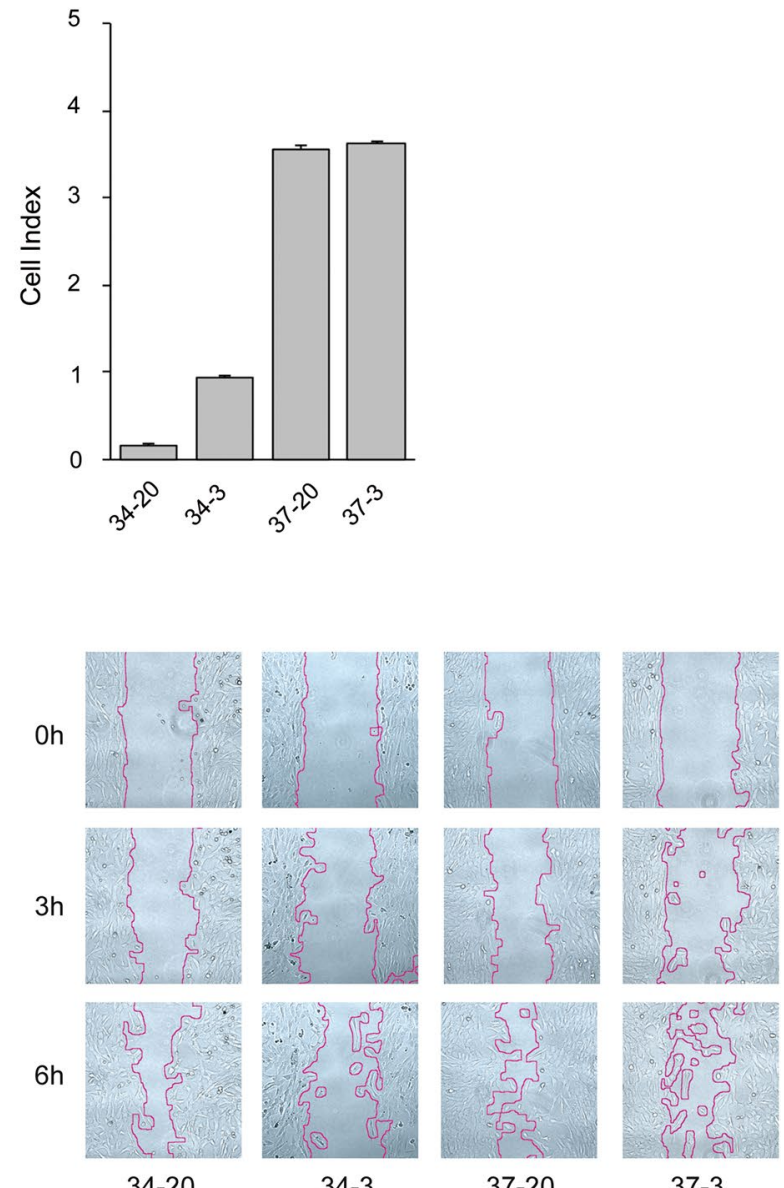

$34-3$

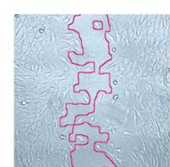

$37-20$

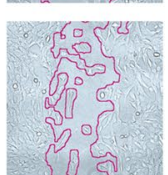

$37-3$

Figure 5. Effects of temperature and oxygen tension on hFOB properties. (A) hFOB cells were seeded at a density of 10 cells $/ \mathrm{cm}^{2}$ and allowed to form colonies for 15 days at $34{ }^{\circ} \mathrm{C} / 20 \% \mathrm{O}_{2}(34-20) ; 34{ }^{\circ} \mathrm{C} / 3 \% \mathrm{O}_{2}(34-3)$; $37^{\circ} \mathrm{C} / 20 \% \mathrm{O}_{2}(37-20)$ and $37^{\circ} \mathrm{C} / 3 \% \mathrm{O}_{2}(37-3)$. After fixation and staining with crystal violet, colonies were counted and depicted as mean \pm standard deviation $(\mathrm{n}=3)$. B) hFOBs were seeded at a density of $2 \times 10^{2} / \mathrm{cm}^{2}$ in each well of an impedance reader E-plate and cell growth was non-invasively monitored every $2 \mathrm{~h}$ over a time lapse of 8 days. Impedance was expressed as a Cell Index (CI) value. Representative graph from xCELLigence system are shown for growth curves of hFOB cultured at specified temperature and oxygen conditions. (C) CI-values were compared at 6 days after seeding. (D) Cell wounding and assessment of migratory behavior of $\mathrm{hFOB}$ at passages 5-7 at various culture conditions. Quantitative image data acquisition was performed with Live Cell Imager CELL IQ and analysis was performed with CellActivision Software (Yokogama). Results for quantitative analysis of percentage of gap closure at the different culture conditions are shown for $3 \mathrm{~h}$ and $6 \mathrm{~h}$ after gap opening. (E) Representative images at given conditions are shown. Gap closures are highlighted at $0 \mathrm{~h}$, $3 \mathrm{~h}$ and $6 \mathrm{~h}$ after gap opening with pink lines.

these conditions, $3 \%$ oxygen supported a similar number of colonies as in the first round, while at $20 \% \mathrm{O}_{2}$ secondary colony numbers were found to be significantly reduced (Fig. 6C). At higher passages, cells increased in size and proliferation decreased. Less self-renewal potential at elevated cell passage (P19 vs P6) was accompanied 
A
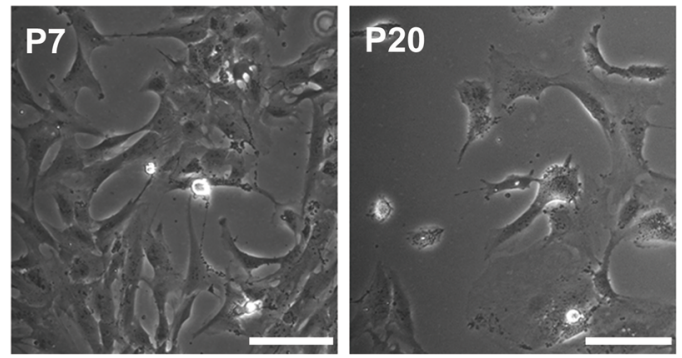

B

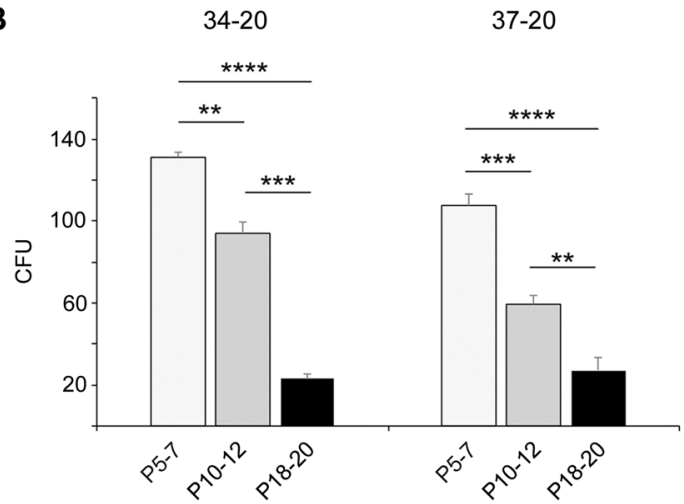

C

$1^{\text {st }}$ round $\quad 2^{\text {nd }}$ round

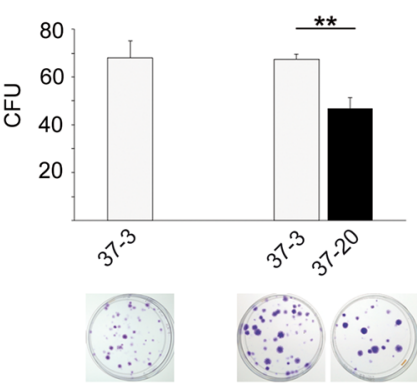

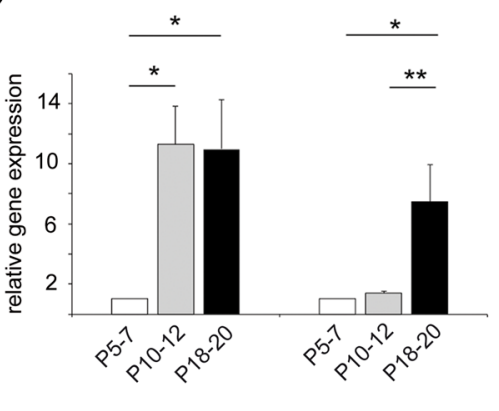

CDKN2A (p16) CDKN1A (p21)
E

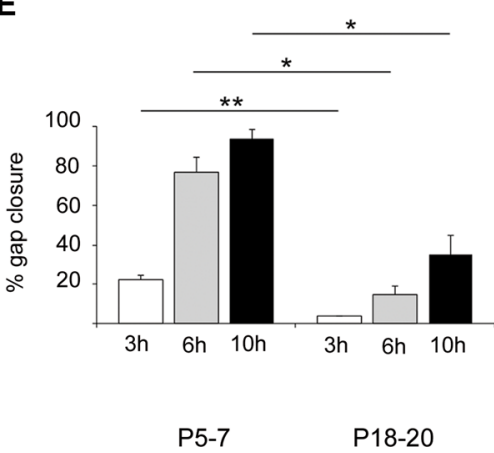

$\mathbf{F}$
IL6

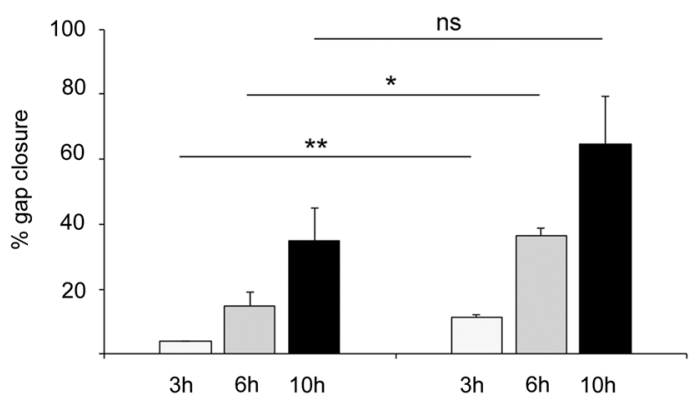

G

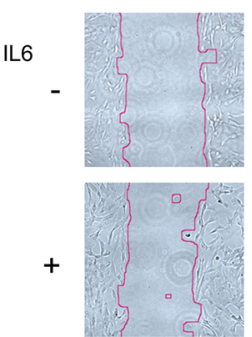

Oh

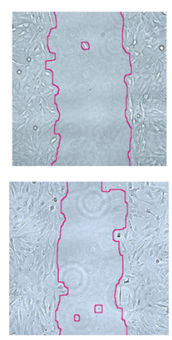

$3 \mathrm{~h}$
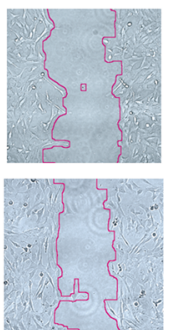

$6 \mathrm{~h}$

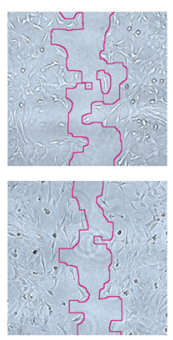

$10 \mathrm{~h}$

Figure 6. Effects of long-term culture on hFOB stemness and migratory behavior. (A) Brightfield microscopy (magnification $\times 200$, scale bar $100 \mu \mathrm{m}$ ) of hFOB cells passage 7 and 20. (B) CFU-F of hFOB cells of passages $5-7,10-12$ and 18-20 were performed in triplicates at the given environmental settings. Cells were seeded at a density of 10 cells $/ \mathrm{cm}^{2}$ (600 cells/plate) and incubated for 15 days. Cells were stained with Crystal violet. Mean number \pm standard deviation (SD) of resulting colony-forming units fibroblasts (CFU-F) was determined. (C) Colony formation (2nd round) using cells derived from a previously formed colony (1st round) was performed in triplicate at the given temperature and oxygen tension. Cells were seeded at a density of $10 \mathrm{cells} / \mathrm{cm}^{2}(600$ cells/plate) and incubated for 15 days. After the 1st round, cells were trypsinized and seeded again for a 2nd term of colony formation (density of 10 cells $/ \mathrm{cm}^{2}$ ). (D) mRNA levels within hFOB cells at passage 10-12 or passage 18-20 encoding CDKN2A (p16) and CDKN1A (p21) were measured by RT-qPCR, normalized to YWHAZ and plotted as fold induction relative to the levels of hFOB P5-7. (E) Migratory behavior of passage 5-7 and passage $18-20$ cells at $34^{\circ} \mathrm{C} 20 \% \mathrm{O}_{2}$. Determination of \%-gap closure after $3 \mathrm{~h}, 6 \mathrm{~h}$ and $10 \mathrm{~h}$. (F) Migration of hFOB passage 18-20 in the presence of IL-6 $(10 \mathrm{ng} / \mathrm{ml})$ and without IL-6 (CTR). Determination of $\%$-gap closure after $3 \mathrm{~h}, 6 \mathrm{~h}$ and $10 \mathrm{~h}$. (G) Representative images of the gap closure quantified in (F) after 0, 3, 6 and $10 \mathrm{~h}$ post IL- 6 treatment.

by (i) enhanced transcription of the cell cycle regulators p16 (CDKN2A) and p21 (CDKN1A) (Fig. 6D) and (ii) significant loss of migratory properties at $34^{\circ} \mathrm{C}$ and $20 \%$ oxygen (Fig. 6E). Low-passage cells (P7) were able to significantly reduce the gap (approx. $80 \%$ closure), while high passage cells (P18) closed the gap only up to $20 \%$ (Fig. 6E). 
In case of MSC it is known that pro-inflammatory cytokines such as interleukin 6 (IL6), interferon gamma $(\mathrm{IFN} \gamma)$ or Tumor Necrosis Factor alpha (TNFa) lead to increased cell migration ${ }^{23}$. Hence, migratory behavior of hFOB treated with $10 \mathrm{ng} / \mathrm{ml}$ of human IL6 was monitored. In comparison to mock-treated cells, IL6 significantly rescued the migration deficit of senescent hFOB at the wounded site. After $6 \mathrm{~h}$ at $34^{\circ} \mathrm{C}$ and $20 \%$ oxygen, the gap width in IL6-exposed cell cultures was significantly smaller than the one in untreated cells (Fig. 6F,G).

\section{Discussion}

The hFOB 1.19 cell line has been generated by introducing a temperature-sensitive isotype of the SV40 large T antigen into primary human cells isolated from fetal bone. Upon induction, hFOB cells readily undergo osteogenic differentiation, strongly activate expression of osteogenic factors and reliably form mineralized nodules ${ }^{24}$. Further characterization of this cell line has shown only minor chromosome abnormalities, when compared to transformed osteosarcoma cell lines. Most important however, hFOB form bone in vivo ${ }^{25}$. Yen and colleagues have also shown that hFOB display a specific set of cell surface markers, similar to that found in bmMSC. In addition to their predetermined osteogenic fate, $\mathrm{hFOB}$ are multipotent and differentiate into many other mesodermal lineages. Notably, they can also acquire a neural-like phenotype ${ }^{17}$. hFOB bear characteristics of skeletal stem cells (SSC) and exhibit mesenchymal multi-lineage differentiation potential, show high migratory behavior and express a large variety of cell surface antigens common to mesenchymal stromal cells. Based on these findings, hFOB appear predestined to act as a suitable cell model in human mesenchymal cell biology. A surrogate system for MSC should not only provide a reliable source of material and display a similar differentiation potential but it should encompass the behavior of primary cells as a mirror of the in vivo niche. We therefore extended these studies by further characterizing of hFOB according to attributes, which are amenable for comparative analyses providing a better understanding of MSC biology, in particular also tackling mechanisms and pathways driving MSC aging.

BmMSC are progenitor cells with high proliferation potential at an undifferentiated state. In parallel, they bear the ability to bring forth more specialized precursors, which are capable of differentiating into lineages of mesenchymal character, such as bone, fat, and various other collagenous connective tissues ${ }^{26}$. The recent identification of human SSC, which generate progenitor cells of bone, cartilage, and stroma, but not fat has questioned the rank of bmMSC being the stromal stem cell ${ }^{27,28}$. bmMSC are now considered a more committed progenitor population descending from SSC, or, they could now also be conceived a heterogeneous population comprising more restricted progenitor cell type ${ }^{29}$. As such there are reasons to believe that an important function of bmMSC is to establish the bone marrow niche as cell explants from adult bone marrow contain significant numbers of progenitors that are committed to the osteogenic lineage. Indeed it could be shown that upon re-implantation of selected specialized osteo-progenitors compact bone is formed but not bone marrow ${ }^{29,30}$. In line with that, bmMSC also bring forth pre-adipocyte-like cells.

Notably, osteogenic cell populations, which contain periostal cells or trabecular bone cells exhibit a high expression of the surface antigen, CD146 (melanoma cell adhesion molecule) $)^{30}$. CD146 is a key marker for MSC; it is generally detected in MSC isolated from various tissues and endows cells with clonogenicity and multipotency $^{31}$. Along with CD146, CD90, also CD44, a marker for MSC stemness ${ }^{32}$ is highly expressed by hFOB (S1). No significant variations were observed on the expression of these three surface molecules upon long-term subculture, which is in contrast to reports on MSC (data not shown). Nevertheless, it has already been reported that immortalization via SV40 can maintain differential expression of functional markers that are present in the primary cells, among them CD44 as well as CD106 $6^{33}$.

Due to the concomitant expression of MSC-associated key molecules CD90 and CD44, and their multilineage differentiation potentials, we infer that hFOB are in reality fetal stem cell-like cells rather than specialized osteoblasts. For all those features that hFOB have in common with MSC, we believe that the hFOB1.19 line can be considered a valuable model system for basic research in MSC. Most important in this context is the finding that hFOB acquire a senescence-like phenotype, which is in stark contrast to the well-established model of hTERT-MSC ${ }^{34,35}$. The nature of high-passage cells certainly needs further characterization. Nevertheless, our observations and analyses indicate that conditionally immortalized hFOB have the potential to preserve a MSClike physiological state as would be expected under normal conditions. For this purpose we adjusted culture conditions and protocols.

The impact of long-term cultivation on cellular fitness is well documented in MSC: at a pre-senescent state, self-renewal and migratory properties drastically decline ${ }^{18,36,37}$. The migratory potential can be enhanced in old MSC by specific cytokines ${ }^{38}$, only one being interleukin-6 (IL6). This biological trait of MSC cannot be reproduced by standard cell lines, for example hTERT-MSC ${ }^{39,40}$, most likely because they efficiently escape senescence. This confirms its potential as a novel model as conditionally immortalized hFOB largely preserve a MSC-like cell physiological state comparable to normal in vivo conditions. The fact that long-term culture impacts the hFOB's self-renewal and migratory capacities suggests that hFOB exhibit a higher degree of plasticity compared to most common MSC models. Also in good concordance to bmMSC, the hFOB self-renewal potential were significantly reinforced when cultivation was undertaken at atmospheric conditions of $3 \% \mathrm{O}_{2}{ }^{41-43}$. Hypoxia supported clonogenicity of hFOB but reduced migration in a scratch assay. Although several studies demonstrated hypoxia enhances migration of $\mathrm{MSC}^{44}$, other authors have shown that gap closure occurred more rapidly at normoxic conditions ${ }^{45,46}$, comparable to our findings with hFOB.

In addition to that, the possibility to develop hFOB reporter cell lines makes them superior to MSC to study stem cell-intrinsic and extrinsic questions. This is an important feature of hFOB, because it would overcome the limitation of cell line generation in the MSC field, as MSC, similar to most primary cells isolated from adult tissues, have a finite capacity to replicate in vitro. Together with the propensity of being capable in vitro to form 
3D mesenspheres, which resemble tissues formed in vivo, hFOB1.19 represent a novel means to reproduce cellular functionalities of primary MSC in the context of their microenviroment.

In conclusion, hFOB are not only resembling $\mathrm{MSC}^{44,45}$, but exhibit many common features, for instance when being cultivated at physiological oxygen conditions, stemness is enhanced, proliferation is stimulated and migratory behavior becomes biased. Based on our observations, it became clear that long-term cultivated hFOB gain cellular history, they refrain from immaculate self-renewal, thus they display changes, which resemble a cellular aging phenotype.

\section{Methods}

Cell culture. The immortalized human fetal osteoblast cell line hFOB1.19 (hFOB) was purchased from American Tissue Type Culture (ATTC) and cultured according to the protocol specified by the repository (ATCC ${ }^{\circ}$ CRL-11372 ${ }^{\mathrm{ms}}$ ). For in vitro proliferation, hFOB1.19 cells were maintained in DMEM:Ham's F12 (Sigma, D6421)

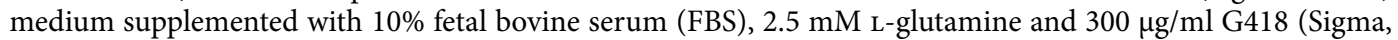
G8168), designated herein growth medium. hFOB cells were cultured in a humidified incubator at atmospheric conditions of either $20 \%$ or $3 \% \mathrm{O}_{2}$, always supplemented with $5 \% \mathrm{CO}_{2}$ at temperatures of 34,37 or $39{ }^{\circ} \mathrm{C}$.

Immunophenotyping. For surface antigen detection, $5 \times 10^{5}$ ells were washed and blocked for $1 \mathrm{~h}$ with PBS containing $4 \%$ FBS after detachment with $0.25 \%$ trypsin/EDTA. Cells were characterized with fluorescein isothiocyanate- or phycoerythrin-conjugated primary antibodies for human surface antigens and compared with appropriate isotype controls. The following conjugated monoclonal antibodies were used for hFOB immunophenotyping: CD90 PE (Biologend 5E10/328110), CD73 PE (Biolegend AD2/344003), CD45 PE (Biolegend HI30/304008), CD19 PE (Biolegend HIB19/302207), mouse IgG1k Isotype PE (Biolegend MOPC-21/400112), CD 44 PE (BD Bioscience 550989), CD106 PE (BD Biosciences 555647), CD34 PE (BD Bioscience 555822) and CD105 FITC (Ancell 326040), CD146 PE (Biolegend P1H12/361006). Flow cytometry analysis was performed using CytoFlex S with CytoExpert and Kaluza softwares (Beckman Coulter).

Reporter cell lines. A monoclonal cell line expressing enhanced green fluorescent protein (eGFP) under the control of the human ubiquitinase (UbC) Promoter (hFOB-eGFP) was generated using the lentivirus vector FG $12^{47}$ (Addgene, Plasmid \#14884). A transgenic reporter cell line expressing eGFP under the control of the human osteocalcin (hOC) promoter was obtained by cloning the respective sequence from hOC-pGL3 plasmid ${ }^{48}$ into the vector peGFP-N1 (Clontech) using KpnI and BglII restriction sites (phOC-eGFP). The hOC-eGFP cassette was excised by XhoI and AgeI endonucleases and ligated in to the lentivirus expression plasmid FG12 (Addgene, Plasmid \#14884), which was digested with the restriction enzymes SalI and AgeI (pLV-hOC-eGFP). For production of recombinant lentivirus, adherent HEK 293FT cells were used for virus packaging and production. One day prior transfection, $5 \times 10^{6}$ HEK 293 FT cells were grown in DMEM-medium containing 10\% FBS (without antibiotics) in a $100 \mathrm{~mm}$ dish. Next, HEK293T cells in $10 \mathrm{ml}$ of basal DMEM (Sigma) were transfected with 4.4 $\mu \mathrm{g}$ of expression plasmid (FG12 or pLV-hOC-eGFP), $11 \mu \mathrm{g}$ of psPAX2 and $3.6 \mu \mathrm{g}$ of pMD2.G plasmid using 54 $\mu \mathrm{l}$ of lipofectamine 2000 (Life Technologies) as described previously ${ }^{49}$. After $6 \mathrm{~h}$ incubation, the medium containing the transfection mixture, was replaced with $6 \mathrm{ml}$ of fresh complete DMEM (10\% FBS, 1\% L-glutamine) without antibiotics and the cells were further incubated for another $48 \mathrm{~h}$ at $37^{\circ} \mathrm{C}$ with $5 \% \mathrm{CO}_{2}$ in a humidified atmosphere. The virus particles were harvested by collecting the supernatant after centrifugation at $2000 \times g$ for 10 min at $4{ }^{\circ} \mathrm{C}$. The supernatant was filtered through a $0.45-\mu \mathrm{m}$ syringe filter and stored at $-80^{\circ} \mathrm{C}$.

Reporter cell lines were generated by transducing hFOB with the corresponding viral vector at a multiplicity of infection (MOI) of 5-10. Transduction was performed by centrifugation at $1000 \times g$ for 50 min at RT and transduced cells were expanded and monitored for eGFP expression. Reporter cell lines were sorted with FACS Aria III (BD Biosciences). hFOB-hOC eGFP cells were sorted according to a low eGFP expression and amplified as a polyclonal cell line.

Reporter activity of hFOB-hOC eGFP was assessed by comparing eGFP expression of cells incubated at the non-permissive temperature of $39^{\circ} \mathrm{C}$ with their basal activity at $34^{\circ} \mathrm{C}$. Briefly, cells were seeded into 24 -well tissue culture plates at a density of $10^{5}$ cells/well. After incubation overnight at $34^{\circ} \mathrm{C}$ to allow attachment, cells were transferred to the non-permissive temperature of $39^{\circ} \mathrm{C}$ for 3 days. Control cells were left at $34^{\circ} \mathrm{C}$. Emissions of green fluorescence were visualized by fluorescence microscopy (DMIL, Leica) and quantified by flow cytometry using Cytoflex S and Kaluza Analysis software (Beckman Coulter).

3D culture. Mesensphere were generated in ultra-low attachment U-bottom 96-well plate (Greiner). Plates were coated with sterile-filtered 3\% pluronic F-127 (Sigma, P2243) in PBS and were either used the same day or aseptically stored at $4{ }^{\circ} \mathrm{C}$. Cells were seeded at the indicated concentration $\left(10^{3}-10^{4}\right.$ cells/well $)$ and allowed to aggregate into spheroids for $48 \mathrm{~h}$ in growth medium at $34^{\circ} \mathrm{C}$ and $5 \% \mathrm{CO}_{2} / 20 \% \mathrm{O}_{2}$ before further processing. For induction of differentiation, after the sedimentation phase, spheroids were transferred to $39{ }^{\circ} \mathrm{C}$ and $5 \% \mathrm{CO}_{2} / 20 \%$ $\mathrm{O}_{2}$ either in growth medium (osteogenesis), or in adipogenic medium as indicated in the section "Differentiation" studies. For experiments in serum-free medium, fetal bovine serum was substituted in the growth medium with 15\% KnockOut ${ }^{\text {th }}$ Serum Replacement (KSR) (Gibco, \#10828028). $10 \mathrm{ml}$ of a cell suspension containing $5 \times 10^{5}$ cells $/ \mathrm{ml}$ in KSR-medium were added to a sterile uncoated culture dish exhibiting a surface repellent to cells, thereby forcing cells to form spheroids, which in due course can be also grown under this conditions.

Immunofluorescence, cytochemical staining and histology. Accumulation of extra-cellular calcium was assayed using Xylenol Orange (Fluka, \#33825) as a living-cell dye, or alternatively after fixation with Alizarin Red (Fluka, \#440563). Xylenol Orange was dissolved in water to a $5 \mathrm{mM}$ solution, and sterile-filtered 
using a $0.22-\mu \mathrm{m}$ filter. Samples were incubated overnight at a final concentration of $20 \mu \mathrm{M}$. Before imaging, cells were washed and growth medium was added to prevent non-specific background fluorescence. Mineral content was also detected by Alizarin Red staining. Cells were washed and fixed with $4 \%$ paraformaldehyde for 30 min. Alizarin Red S staining (2\% aqueous solution $\mathrm{pH}$ to 4.1-4.3) was performed for 45-60 min at room temperature.

Autodot (Abcepta, \#SM1000a) was applied to label lipid droplet formation as described previously ${ }^{50}$. Briefly, spheroids were first washed with PBS and incubated with $100 \mu \mathrm{M}$ Autodot for $1 \mathrm{~h}$. After three washes with PBS, spheroids were transferred into phenol-red free medium for imaging.

Quantitative PCR. Total RNA was isolated with the RNeasy Plus Mini Kit (Qiagen), quantified with a NanoDrop 1000 spectrophotometer (Thermo Scientific) and stored at $-80^{\circ} \mathrm{C}$. Complementary DNA (cDNA) synthesis was performed with 100-500 ng of total RNA using the RevertAid First Strand cDNA Synthesis Kit (Thermo Scientific). Quantitative PCR was performed on an AriaMX Real-Time PCR System (Agilent) with the Luna Universal qPCR Master Mix (New England Biolabs). All PCR reactions were prepared three times in duplicates. To determine primer specificity, melting curves were performed after 40 cycles of PCR. Fold difference in gene expression was calculated using the $\triangle \Delta \mathrm{Ct}$ method and normalization according to the expression of the references gene YWHAZ. Primer sequences are given as supplement (SI, Table).

Differentiation. All differentiation experiments were conducted at $39{ }^{\circ} \mathrm{C}$ and $5 \% \mathrm{CO}_{2} / 20 \% \mathrm{O}_{2}$. For osteogenic induction, monolayers were incubated at $34^{\circ} \mathrm{C}$ and $5 \% \mathrm{CO}_{2} / 20 \% \mathrm{O}_{2}$ in growth medium until the cell lawn reached confluency. The culture was then transferred to $39^{\circ} \mathrm{C}$ and $5 \% \mathrm{CO}_{2} / 20 \% \mathrm{O}_{2}$. In the case of adipogenic differentiation, incubation was performed in adipogenic medium consisting of growth medium with the addition of $0.5 \mathrm{mM}$ isobutyl-methylxanthine (Sigma, I5879), $1 \mu \mathrm{M}$ dexamethasone (Sigma, D4902), $10 \mu \mathrm{M}$ insulin (Sigma, 19278), and $60 \mu \mathrm{M}$ indomethacin (Sigma, I7378).

Colony formation. In order to assess colony formation, 10 cells were seeded per $\mathrm{cm}^{2}$ in triplicates in a 100 $\mathrm{mm}$ culture plate. The colonies were counted after 15 days in culture and the average number of colonies of three plates was calculated. A colony was defined as consisting of at least 50 cells. The analysis was performed for different culture conditions or cell passages.

An iterated colony forming assay was performed as follows: colonies obtained at $37^{\circ} \mathrm{C} 3 \% \mathrm{O}_{2}$ from an intermediate cell passage (p12) were detached and subjected to a second term of colony formation. $10 \mathrm{cells} / \mathrm{cm}^{2}$ were seeded and plates were incubated either at $37^{\circ} \mathrm{C} / 3 \% \mathrm{O}_{2}$ or $37^{\circ} \mathrm{C} / 20 \% \mathrm{O}_{2}$ for 15 days in the presence of G418.

Real-time impedance-based monitoring of cell proliferation. Cell proliferation was assessed by means of the online monitoring xCELLigence system equipped with an E-Plate (ACEA Biosciences Inc.). 100 cells were seeded in each well of an E-plate in growth medium. The impedance value of each well was automatically monitored by the device every $2 \mathrm{~h}$ for the duration of $180 \mathrm{~h}$ and expressed as a cell index, or CI-value. Impedance was acquired for four different culture conditions: $34^{\circ} \mathrm{C}$ at $20 \% \mathrm{O}_{2}, 34^{\circ} \mathrm{C}$ at $3 \% \mathrm{O}_{2}, 37^{\circ} \mathrm{C}$ at $20 \% \mathrm{O}_{2}$, and $37^{\circ} \mathrm{C}$ at $3 \% \mathrm{O}_{2}$.

Cell migration. hFOB migration capability was assessed as follows: a 2-well silicone insert (Culture-insert 2 well, Ibidi) was placed in a 12-well microtiter plate and used to create a defined cell-free gap of $500 \pm 100 \mu \mathrm{m}$. hFOB cells $\left(2 \times 10^{5}\right.$ cells in $70 \mu$ l growth medium $)$ were seeded in each reservoir and incubated overnight. In case of IL6 treatment hFOB cells were pre-treated with IL6 $(10 \mathrm{ng} / \mathrm{ml})$ before seeding in the culture insert. IL6 treatment was maintained throughout the entire migration assay. After cell attachment, the insert was removed the following day and cell migration was analyzed by evaluating gap closure over $6 \mathrm{~h}$ using a live-cell imager (Cell IQ, Chip-Man technologies). The progress of gap closure was assessed every $30 \mathrm{~min}$ by obtaining photomicrographs starting at the initial time point until completion of the study.

The rates of gap closure were analyzed by applying the scratch wound measurement tool of the CellActivision software (Yokogawa Electric Corporation). Rates of gap closure were determined both by assessing gap width over time, as well as by quantifying the area devoid of cells over time. All assays were performed in triplicate.

Statistical analysis. All experiments were carried out independently for at least three times. Data were expressed as mean \pm standard deviation. Statistical significance was evaluated using a two-tailed Student's $t$ test and $\mathrm{P}$ values of $\leq 0.05$ were considered significant $\left.{ }^{\star}\right)$, whereas a significance of ${ }^{\star *}$ refers to $\mathrm{p} \leq 0.01$ and ${ }^{* * *}$ denotes a $\mathrm{p} \leq 0.001$, respectively.

Received: 4 February 2021; Accepted: 30 April 2021

Published online: 25 May 2021

\section{References}

1. Caplan, A. I. Mesenchymal stem cells. J. Orthop. Res. 9, 641-650. https://doi.org/10.1002/jor.1100090504 (1991).

2. Viswanathan, S. et al. Mesenchymal stem versus stromal cells: International Society for Cell and Gene Therapy (ISCT(R)) Mesenchymal Stromal Cell committee position statement on nomenclature. Cytotherapy 21, 1019-1024. https://doi.org/10.1016/j.jcyt. 2019.08.002 (2019). 
3. Gnani, D. et al. An early-senescence state in aged mesenchymal stromal cells contributes to hematopoietic stem and progenitor cell clonogenic impairment through the activation of a pro-inflammatory program. Aging Cell 18, e12933. https://doi.org/10.1111/ acel.12933 (2019).

4. Czekanska, E. M., Stoddart, M. J., Richards, R. G. \& Hayes, J. S. In search of an osteoblast cell model for in vitro research. Eur. Cell Mater. 24, 1-17 (2012).

5. Kartsogiannis, V. \& Ng, K. W. Cell lines and primary cell cultures in the study of bone cell biology. Mol. Cell Endocrinol. 228, 79-102. https://doi.org/10.1016/j.mce.2003.06.002 (2004).

6. Czekanska, E. M., Stoddart, M. J., Ralphs, J. R., Richards, R. G. \& Hayes, J. S. A phenotypic comparison of osteoblast cell lines versus human primary osteoblasts for biomaterials testing. J. Biomed. Mater. Res. A 102, 2636-2643. https://doi.org/10.1002/jbm.a. 34937 (2014).

7. Simonsen, J. L. et al. Telomerase expression extends the proliferative life-span and maintains the osteogenic potential of human bone marrow stromal cells. Nat. Biotechnol. 20, 592-596. https://doi.org/10.1038/nbt0602-592 (2002).

8. Kang, S. K. et al. Expression of telomerase extends the lifespan and enhances osteogenic differentiation of adipose tissue-derived stromal cells. Stem Cells 22, 1356-1372. https://doi.org/10.1634/stemcells.2004-0023 (2004).

9. Li, Y. et al. Senescence of mesenchymal stem cells (Review). Int. J. Mol. Med. 39, 775-782. https://doi.org/10.3892/ijmm.2017.2912 (2017).

10. Burns, J. S. et al. Tumorigenic heterogeneity in cancer stem cells evolved from long-term cultures of telomerase-immortalized human mesenchymal stem cells. Cancer Res. 65, 3126-3135. https://doi.org/10.1158/0008-5472.CAN-04-2218 (2005).

11. Takeuchi, M. et al. Chromosomal instability in human mesenchymal stem cells immortalized with human papilloma virus E6, E7, and hTERT genes. In Vitro Cell Dev. Biol. Anim. 43, 129-138. https://doi.org/10.1007/s11626-007-9021-9 (2007).

12. Takeuchi, M. et al. Transcriptional dynamics of immortalized human mesenchymal stem cells during transformation. PLoS One 10, e0126562. https://doi.org/10.1371/journal.pone.0126562 (2015).

13. Turinetto, V., Vitale, E. \& Giachino, C. Senescence in human mesenchymal stem cells: Functional changes and implications in stem cell-based therapy. Int. J. Mol. Sci. 17, 1164. https://doi.org/10.3390/ijms17071164 (2016).

14. Schimke, M. M., Marozin, S. \& Lepperdinger, G. Patient-specific age: The other side of the coin in advanced mesenchymal stem cell therapy. Front. Physiol. 6, 362. https://doi.org/10.3389/fphys.2015.00362 (2015).

15. Reitinger, S. et al. Systemic impact molds mesenchymal stromal/stem cell aging. Transfus. Apher. Sci. 52, 285-289. https://doi.org/ 10.1016/j.transci.2015.04.008 (2015).

16. Qin, Y., Wang, L., Gao, Z., Chen, G. \& Zhang, C. Bone marrow stromal/stem cell-derived extracellular vesicles regulate osteoblast activity and differentiation in vitro and promote bone regeneration in vivo. Sci. Rep. 6, 21961. https://doi.org/10.1038/srep21961 (2016).

17. Yen, M. L. et al. Multilineage differentiation and characterization of the human fetal osteoblastic 1.19 cell line: A possible in vitro model of human mesenchymal progenitors. Stem Cells 25, 125-131. https://doi.org/10.1634/stemcells.2006-0295 (2007).

18. Gu, Y. et al. Changes in mesenchymal stem cells following long-term culture in vitro. Mol. Med. Rep. 13, 5207-5215. https://doi. org/10.3892/mmr.2016.5169 (2016).

19. Wagner, W. et al. How to track cellular aging of mesenchymal stromal cells?. Aging (Albany NY) 2, 224-230 (2010).

20. Alimperti, S. et al. Serum-free spheroid suspension culture maintains mesenchymal stem cell proliferation and differentiation potential. Biotechnol. Prog. 30, 974-983. https://doi.org/10.1002/btpr.1904 (2014).

21. Xiao, L. \& Tsutsui, T. Characterization of human dental pulp cells-derived spheroids in serum-free medium: Stem cells in the core. J. Cell Biochem. 114, 2624-2636. https://doi.org/10.1002/jcb.24610 (2013).

22. Wagner, W. et al. Aging and replicative senescence have related effects on human stem and progenitor cells. PLoS One 4, e5846. https://doi.org/10.1371/journal.pone.0005846 (2009).

23. Ayaloglu-Butun, F., Terzioglu-Kara, E., Tokcaer-Keskin, Z. \& Akcali, K. C. The effect of estrogen on bone marrow-derived rat mesenchymal stem cell maintenance: Inhibiting apoptosis through the expression of Bcl-xL and Bcl-2. Stem Cell Rev. 8, 393-401. https://doi.org/10.1007/s12015-011-9292-0 (2012).

24. Harris, S. A., Enger, R. J., Riggs, B. L. \& Spelsberg, T. C. Development and characterization of a conditionally immortalized human fetal osteoblastic cell line. J. Bone Miner. Res. 10, 178-186. https://doi.org/10.1002/jbmr.5650100203 (1995).

25. Subramaniam, M. et al. Further characterization of human fetal osteoblastic hFOB 1.19 and hFOB/ER alpha cells: Bone formation in vivo and karyotype analysis using multicolor fluorescent in situ hybridization. J. Cell Biochem. 87, 9-15. https://doi.org/10.1002/ jcb.10259 (2002).

26. Pittenger, M. F. et al. Multilineage potential of adult human mesenchymal stem cells. Science 284, 143-147. https://doi.org/10. $1126 /$ science.284.5411.143 (1999).

27. Ambrosi, T. H., Longaker, M. T. \& Chan, C. K. F. A revised perspective of skeletal stem cell biology. Front. Cell Dev. Biol. 7, 189. https://doi.org/10.3389/fcell.2019.00189 (2019).

28. Chan, C. K. F. et al. Identification of the human skeletal stem cell. Cell 175, 43-56 e21. https://doi.org/10.1016/j.cell.2018.07.029 (2018).

29. Sacchetti, B. et al. No identical "mesenchymal stem cells" at different times and sites: Human committed progenitors of distinct origin and differentiation potential are incorporated as adventitial cells in microvessels. Stem Cell Rep. 6, 897-913. https://doi.org/ 10.1016/j.stemcr.2016.05.011 (2016).

30. Sacchetti, B. et al. Self-renewing osteoprogenitors in bone marrow sinusoids can organize a hematopoietic microenvironment. Cell 131, 324-336. https://doi.org/10.1016/j.cell.2007.08.025 (2007)

31. Lv, F. J., Tuan, R. S., Cheung, K. M. \& Leung, V. Y. Concise review: The surface markers and identity of human mesenchymal stem cells. Stem Cells 32, 1408-1419. https://doi.org/10.1002/stem.1681 (2014).

32. Okolicsanyi, R. K. et al. Human mesenchymal stem cells retain multilineage differentiation capacity including neural marker expression after extended in vitro expansion. PLoS One 10, e0137255. https://doi.org/10.1371/journal.pone.0137255 (2015).

33. Haas, C., Aicher, W. K., Dinkel, A., Peter, H. H. \& Eibel, H. Characterization of SV40T antigen immortalized human synovial fibroblasts: Maintained expression patterns of EGR-1, HLA-DR and some surface receptors. Rheumatol. Int. 16, 241-247. https:// doi.org/10.1007/bf01375656 (1997).

34. Skarn, M. et al. Generation and characterization of an immortalized human mesenchymal stromal cell line. Stem Cells Dev. 23, 2377-2389. https://doi.org/10.1089/scd.2013.0599 (2014).

35. Bischoff, D. S., Makhijani, N. S. \& Yamaguchi, D. T. Constitutive expression of human telomerase enhances the proliferation potential of human mesenchymal stem cells. Biores. Open Access 1, 273-279. https://doi.org/10.1089/biores.2012.0252 (2012).

36. Hong, S. H. et al. Stem cell passage affects directional migration of stem cells in electrotaxis. Stem Cell Res. 38, 101475. https://doi. org/10.1016/j.scr.2019.101475 (2019).

37. Legzdina, D., Romanauska, A., Nikulshin, S., Kozlovska, T. \& Berzins, U. Characterization of senescence of culture-expanded human adipose-derived mesenchymal stem cells. Int. J. Stem Cells 9, 124-136. https://doi.org/10.15283/ijsc.2016.9.1.124 (2016).

38. Ozaki, Y. et al. Comprehensive analysis of chemotactic factors for bone marrow mesenchymal stem cells. Stem Cells Dev. 16, 119-129. https://doi.org/10.1089/scd.2006.0032 (2007).

39. Piper, S. L. et al. Inducible immortality in hTERT-human mesenchymal stem cells. J. Orthop. Res. 30, 1879-1885. https://doi.org/ 10.1002/jor.22162 (2012). 
40. Zhao, Q. et al. Expression of human telomerase reverse transcriptase mediates the senescence of mesenchymal stem cells through the PI3K/AKT signaling pathway. Int. J. Mol. Med. 36, 857-864. https://doi.org/10.3892/ijmm.2015.2284 (2015).

41. Fehrer, C. et al. Reduced oxygen tension attenuates differentiation capacity of human mesenchymal stem cells and prolongs their lifespan. Aging Cell 6, 745-757. https://doi.org/10.1111/j.1474-9726.2007.00336.x (2007).

42. Yu, Y. et al. Effect of hypoxia on self-renewal capacity and differentiation in human tendon-derived stem cells. Med. Sci. Monit. 23, 1334-1339. https://doi.org/10.12659/msm.903892 (2017).

43. Akira, I. et al. The effects of short-term hypoxia on human mesenchymal stem cell proliferation, viability and p16(INK4A) mRNA expression: Investigation using a simple hypoxic culture system with a deoxidizing agent. J. Stem Cells Regen. Med. 11, 25-31 (2015).

44. Xu, W., Xu, R., Li, Z., Wang, Y. \& Hu, R. Hypoxia changes chemotaxis behaviour of mesenchymal stem cells via HIF-1alpha signalling. J. Cell Mol. Med. 23, 1899-1907. https://doi.org/10.1111/jcmm.14091 (2019).

45. Raheja, L. F., Genetos, D. C., Wong, A. \& Yellowley, C. E. Hypoxic regulation of mesenchymal stem cell migration: The role of RhoA and HIF-1alpha. Cell Biol. Int. 35, 981-989. https://doi.org/10.1042/CBI20100733 (2011).

46. Pena-Villalobos, I. et al. Hyperbaric oxygen increases stem cell proliferation, angiogenesis and wound-healing ability of WJ-MSCs in diabetic mice. Front. Physiol. 9, 995. https://doi.org/10.3389/fphys.2018.00995 (2018).

47. Qin, X. F., An, D. S., Chen, I. S. \& Baltimore, D. Inhibiting HIV-1 infection in human T cells by lentiviral-mediated delivery of small interfering RNA against CCR5. Proc. Natl. Acad. Sci. U.S.A. 100, 183-188. https://doi.org/10.1073/pnas.232688199 (2003).

48. Yeung, F. et al. Regulation of human osteocalcin promoter in hormone-independent human prostate cancer cells. J. Biol. Chem. 277, 2468-2476. https://doi.org/10.1074/jbc.M105947200 (2002).

49. Horl, S. et al. CD146 (MCAM) in human cs-DLK1(-)/cs-CD34(+) adipose stromal/progenitor cells. Stem Cell Res. 22, 1-12. https://doi.org/10.1016/j.scr.2017.05.004 (2017).

50. Yang, H. J., Hsu, C. L., Yang, J. Y. \& Yang, W. Y. Monodansylpentane as a blue-fluorescent lipid-droplet marker for multi-color live-cell imaging. PLoS One 7, e32693. https://doi.org/10.1371/journal.pone.0032693 (2012).

\section{Acknowledgements}

G. Lepperdinger was supported by the excellence initiative (Competence Centers for Excellent Technologies, COMET) of the Austrian Research Promotion Agency FFG: "Research Center of Excellence in Vascular Ageing, Tyrol, VASCage" (K-Project number 843536). The experimental study was further supported by funds of the Land Salzburg-Wirtschafts- und Forschungsförderung (20102-P1900166-KZP01-2019; "System Precision on Chips: Fertigungsprozesse und Applikationsforschung-SPOC 2.0"). We also gratefully acknowledge Franz Aschenberger for initial work on reporter cell lines; Eva Dovjak for 3D culture; Astrid Huth for migration assays and cell differentiation and Sebastian König for help in cloning.

\section{Author contributions}

S.M.: conceptualization, methodology, investigation, data curation, formal analysis, writing-original draft, writing-review and editing. B.S.N.: conceptualization, methodology, investigation, data curation, formal analysis, writing-original draft, writing-review and editing. S.I.: investigation. L.W.K.C.: analysis tools and data contribution. G.L.: conceptualization, methodology, formal analysis, supervision, writing-review and editing, funding acquisition.

\section{Competing interests}

The authors declare no competing interests.

\section{Additional information}

Supplementary Information The online version contains supplementary material available at https://doi.org/ 10.1038/s41598-021-90161-2.

Correspondence and requests for materials should be addressed to S.M.

Reprints and permissions information is available at www.nature.com/reprints.

Publisher's note Springer Nature remains neutral with regard to jurisdictional claims in published maps and institutional affiliations.

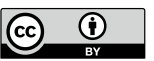

Open Access This article is licensed under a Creative Commons Attribution 4.0 International License, which permits use, sharing, adaptation, distribution and reproduction in any medium or format, as long as you give appropriate credit to the original author(s) and the source, provide a link to the Creative Commons licence, and indicate if changes were made. The images or other third party material in this article are included in the article's Creative Commons licence, unless indicated otherwise in a credit line to the material. If material is not included in the article's Creative Commons licence and your intended use is not permitted by statutory regulation or exceeds the permitted use, you will need to obtain permission directly from the copyright holder. To view a copy of this licence, visit http://creativecommons.org/licenses/by/4.0/.

(C) The Author(s) 2021 